\title{
Decentralization and Participation: The Governance of Common Pool Resources in Nepal's Terai
}

\author{
ARUN AGRAWAL \\ University of Michigan, Ann Arbor, USA \\ and \\ KRISHNA GUPTA \\ Ministry of Commerce and Industry, New Delhi, India

\begin{abstract}
Summary. - Decentralization has emerged as an important instrument of environmental and development policy in the last two decades. Presumed benefits of environmental policy decentralization depend in significant measure on broad participation in the programs that governments create to decentralize decision making related to resource management. This paper uses data from protected areas in Nepal's Terai to examine who participates in environmental decentralization programs. On the basis of our statistical analysis, we highlight the fact that the likelihood of participation in community-level user groups is greater for those who are economically and socially better-off. We also find that individuals who have greater access to and who visit government offices related to decentralization policies more often are also more likely to participate in user groups created by state officials. Finally, we find a negative correlation between education and levels of participation. Our study and analysis support the argument that for decentralization policies to be successful on equity issues, it is important to build institutional mechanisms that encourage poorer and more marginal households to access government officials, improve access to educational opportunities, and create incentives to promote more interactions between less powerful rural residents and government officials.

(C) 2005 Elsevier Ltd. All rights reserved.
\end{abstract}

Key words - environment, protected areas, forests, resource management, Nepal, South Asia

\section{INTRODUCTION}

Decentralization has emerged as an important instrument of environmental and development policy in the last two decades. ${ }^{1}$ Governments play a role in decentralizing decision making and policy implementation to achieve diverse goals: among them social development, democratic participation, resource management, and service provision (Agrawal \& Ostrom, 2001; De Vries, 2000; Willis, Christopher da, \& Haggard, 1999). Although decentralization is sometimes seen as a good in itself, decentralizers defend their policy choices more often on grounds of increased efficiency, greater equity, and higher responsiveness of governments to citizen demands. The presumed superiority of decentralized decision making stems

\footnotetext{
* We would like to thank respondents in the surveyed villages for their cooperation in our data collection efforts, and the UNDP - Kathmandu for providing the funds necessary for the field research. Colleagues at the Nepal Forestry Resources and Institutions Program, especially Birendra Karna and Mukunda Karmacharya, assisted in the data collection effort. Successive drafts of the paper have benefited from comments by Ashwini Chhatre, Clark Gibson, Elinor Ostrom, Kent Redford, and Amy Poteete, and presentations to interested audiences at Indiana University, Yale University, the University of Michigan, and the fourth biennial meeting of the International Forestry Resources and Institutions Program in Nairobi, Kenya, in June 2002. Revisions of the paper were supported by grants from the National Science Foundation (\# SBR 9905443) and the Ford Foundation (\# 950-1160-2). We gratefully acknowledge the help we have received in different forms. Final revision accepted: January 24, 2005.
} 
from the possibility that lower-level decision makers are likely to have better access to information, lower organization costs, and a greater willingness to compete (Fiszbein, 1997; Ribot, 2002). Greater access to decision makers, higher levels of participation by various social groups in decision making, and the accountability of decision makers are often the claimed effects of participation. These are also important as justifications (Andersson, Gibson, \& Lehoucq, 2004; Wunsch \& Olowu, 1997).

Where common pool resources (CPRs) ${ }^{2}$ are concerned, the goal of decentralization policies, as for example in the case of Joint Forest Management in India and Community Forestry in Nepal, has often been to increase participation of rural households in decision making and benefits related to environmental resources. In this paper, we contribute to the existing literature on CPRs and decentralization by examining the factors that help explain local participation in government efforts to decentralize control over resources. The research is important in view of the widespread policy shift toward decentralized control over natural resources in many developing countries. It is also important because many rural communities, especially in Nepal's Terai and more generally in South Asia, are highly differentiated and stratified in terms of power, income and wealth, and social status. In such circumstances, the question of differential participation becomes especially important because the benefits of decentralization policies are seen to improve with greater participation. Presumably, those households that participate more in government efforts to devolve control over resources are also the ones that gain greater benefits from resources. Conversely, nonparticipating households benefit less from decentralization because they are unable to exercise their voice (Hirschman, 1970). Our paper attempts to examine who participates in the governance of CPRs, using a specific study to focus directly on factors that shape the extent of participation in government-sponsored decentralization initiatives.

More specifically, we address the following research question: "In CPR settings in Nepal's Terai region, what are the major factors influencing participation in government-sponsored programs?" To address this question, we examine four hypotheses about participation that focus on economic, social, benefits from CPRs, and access issues. Briefly, we hypothesize that the likelihood of participation in government- sponsored local user groups is greater for households who enjoy a greater level of economic well being; who belong to the upper caste and have a higher level of education; who use more resources from protected areas, and who have more interactions with government officials. Testing these hypotheses helps explore whether existing power holders and those who are wealthier may appropriate a greater proportion of benefits from decentralized control over resources. It also enhances the understanding of the nature of participation and its determinants so as to facilitate better policy design and encourage participation from groups that suffer from a participation deficit. Finally, results from the research can be reviewed in relation to findings from other parts of the world to gain a better sense of the factors that are important in promoting participation in ongoing decentralization efforts.

To examine our research question and hypotheses in a concrete setting, we focus on the Parks and Peoples' Program (PPP), launched in 1994 in Nepal's Terai region. This program attempted to enhance local participation by employing both economic and social incentives. We describe the main features of the PPP and four of the five protected areas in Nepal's Terai that we studied. We then estimate a statistical model to test our hypotheses regarding participation. The data for the empirical test come from a survey of 240 households that we conducted in 1998-99. ${ }^{3}$ The households reside in four settlements in the buffer zones of the parks in the PPP in the Terai. ${ }^{4}$ The settlements were selected randomly from a list of all settlements in the buffer zone. Within each settlement, we randomly selected 60 households from a list of households. After discussing the results and their scope in light of theoretical discussions on participation, we conclude with a consideration of some of the implications of our research for future analyses of participation in CPR management, and the design of CPR-related decentralization policies.

\section{THE PPP AND THE STUDY AREA}

The PPP, sponsored jointly by His Majesty's Government (HMG) of Nepal and the United Nations Development Program, is an example of the ongoing effort to involve communities and local populations in the conservation of forest resources. It is also an important step in the evolution of resource policy in Nepal. 
As a leader among developing countries in setting conservation goals and priorities (Heinen \& Kattel, 1992), the government of Nepal has paid significant attention to formal legislation as a means to involve local rural residents in environmental conservation. Serious formal preservation efforts began in Nepal from 1973 after the passage of the National Parks and Wildlife Conservation Act and the establishment of the Royal Chitwan National Park in central Terai as Nepal's first protected area. Today, Nepal has an extensive network of national parks, wildlife areas, hunting reserves, and conservation areas covering nearly $15 \%$ of the country's total area (Keiter, 1995). ${ }^{5}$ A number of government agencies are involved in the protection effort including the Department of National Parks and Wildlife Conservation founded in 1980, the Ministry of Forestry, the Ministry of Tourism, and the Royal Army whose contingents help enforce many park regulations.

Increasingly, conservation areas and buffer zone management today have come to rely on user groups based in settlements located close to or within protected area boundaries. The objective of management typically includes the provision of economic opportunities and sustainable development of local populations through user group activities. In Nepal, many donor agencies are facilitating the formation of local user groups, especially in buffer zones around parks. ${ }^{6}$ The PPP identified the main problem in the management of Nepal's protected areas to be conflicts between park management authorities, and rural households and their subsistence practices (Budhathoki, 2003; UNDP, 2000). The most notable forms of these conflicts are poaching and encroachment on park resources, and crop damage and human casualties from park animals. ${ }^{7}$ To address these conflicts, the PPP aims to develop alternatives to the use of park resources, provides compensation to local communities for their exclusion from parks, and creates incentives for local peoples to modify their resource harvesting activities in the protected areas. Program documents indicate that the PPP considers higher levels of participation and lower rural poverty as critical ingredients of success in conservation (UNDP, 2000). Creation of formal user groups is a key mechanism to enhance participation and reduce poverty in the PPP strategy. These groups are involved in community organization, savings and rotating credit schemes, and infrastructure construction, affor- estation, skill development, and income-generation programs (Budhathoki, 2003; UNDP, 1994).

The mechanics of the functioning of the PPPsponsored user groups are straightforward (DNPWC, 1998). They exist at the settlement level. All households are eligible members. Villagers meet regularly to contribute savings. Their collective savings are the pool from which eligible candidates draw loans at mutually decided interest rates. The loans are used to encourage productive economic activities, often related to agriculture. PPP's mechanism for investment is called the Internal Credit Fund. In addition, contributions from external actors such as the United Nations Development Program toward a Village Credit Fund create a corpus of money from which user group members can borrow. Borrowers pay back their loans to the user group's Internal Credit Fund. Over time, the Village Credit Fund will be depleted.

The total area for demarcation as the buffer zone for the five protected areas is close to $1,866 \mathrm{sq} \mathrm{km} .{ }^{8}$ The population of the buffer zone (for all five parks) is estimated at 683,000. In its first phase (1994-97), the PPP covered a relatively small proportion of the buffer zone. The details about the area covered during the first phase are presented in Table $1 .{ }^{9}$

Two of the protected areas are contiguousParsa and Suklaphanta Wildlife Reserves. We left out the smaller of these two contiguous protected areas-The Parsa Wildlife Reserve-in selecting the settlements for our research.

\section{STUDIED VARIABLES, DATA, AND ANALYTICAL MODEL}

The field research for this paper is part of a larger study conducted using methods developed by the International Forests Resources and Institutions (IFRI) Program. ${ }^{10} \mathrm{~A}$ team of four researchers familiar with the IFRI research program administered the household instrument, spending between six and eight weeks in each field site. We collected information on demographic characteristics and socioeconomic conditions of the households, including information on land ownership, wealth and income, educational level, caste, household harvests of products from forests, access to the local government office, institutional membership, and occupational aspects. 
Table 1. Basic statistics on the five protected areas in the Nepal Terai

\begin{tabular}{lcccc}
\hline Name & $\begin{array}{c}\text { Area } \\
(\mathrm{sq} \mathrm{km})\end{array}$ & $\begin{array}{c}\text { Population } \\
\text { (in 000's) }\end{array}$ & $\begin{array}{c}\text { Target } \\
\text { number of } \\
\text { user groups } \\
\text { for PPP }\end{array}$ & $\begin{array}{c}\text { Tourism } \\
\text { revenues } \\
\text { (million Rs.) }\end{array}$ \\
\hline Royal Suklaphanta Wildlife Reserve & 155 & 74 & 153 & 0.23 \\
Kosi Tappu Wildlife Reserve & 175 & 172 & 136 & 0.54 \\
Parsa Wildlife Reserve & 499 & 126 & 167 & 0.17 \\
Royal Bardia National Park & 968 & 69 & 460 & 2.72 \\
Royal Chitwan National Park & 932 & 242 & 750 & 48.3 \\
\hline
\end{tabular}

Source: UNDP (1994).

The choice of these variables is based on an extensive literature on determinants of participation, especially in the context of natural resource use.

Some of the earliest research on participation focused on politics, and suggested that an individual's social status, education, and organizational membership have a strong effect on the propensity to participate in political activities (Almond \& Verba, 1963; Dahl, 1961). In general terms, research on participation has examined three broad sets of factors: incentives of individuals, socioeconomic and structural factors, and normative and ideological forces (Verba, Schlozman, Brady, \& Nie, 1993). Analogous research on associations, interest groups, and collective action has also developed formal models of participation, and emphasized the importance of taking costs and benefits of participation into account (Moe, 1980; Olson, 1965). This research suggests that to explain participation it is important to consider both economic and social variables at the participating household level, as also factors that affect benefits and costs to households.

Studies of participation in natural resource management have tended to support the more general arguments above, even as they have identified specific variables that should be taken into account. Many existing studies have also been highly concerned with questions of equity and distribution in participation (Agarwal, 2001; Botchway, 2001; Teklu \& Asefa, 1999). Land and livestock holding are commonly used as indicators of economic status and its variations (Adhikari, Di Falco, \& Lovett, 2004; Kumar, 2002). In rural areas in Nepal, remittances from outmigrants are common, and the availability of such income can raise economic status substantially. Thus sources of nonagricultural contributions to the household income can also exert a powerful influence on willingness to participate in local user groups, even if the direction of this influence is unclear. ${ }^{11}$

Caste is a commonly used indicator of social status in much of South Asia. However, the exact status of numerous castes is highly context specific (Lise, 2000). Education is similarly an important variable that can serve as an indicator of both social status and economic opportunities (Adhikari et al., 2004; Stem, Lassoie, Lee, Deshler, \& Schelhas, 2003). In addition, household size can significantly influence social and economic status, including labor availability, benefits households derive from forests, and ability to tolerate risks by smoothing income fluctuations over time (Naik, 1997).

In the context of CPRs, levels of harvested products from forests are a useful indicator of the benefits to households from their participation in state-sponsored user groups. They are also a rough measure of the dependence of the household on forests. A number of scholars have focused on benefits to households and dependence as an important influence on institutional durability and resource sustainability (Kant, 2000; Kaushal \& Kala, 2004; Netting, 1981). The results of these studies indicate clear differences among scholars about whether households that rely use more forest products are more or less likely to participate in governance.

In addition to the above variables, it is necessary also to assess another important aspect of user organizations in the CPR settings upon which we focus: the role of the government. When governments facilitate the creation of organizations/groups to manage CPRs, a significant part of the agenda is designed by state agencies. Government officials often decide about the objectives of the community-level groups, the obligations of members, and the benefits they receive. Careful initiatives can re- 
duce costs of local collective action substantially. Ill-designed interventions can undermine all possibility of widespread participation. It is important therefore to pay attention to the relationship between government officials and residents in local communities, the extent to which government officials are accessible to local residents, and how such accessibility affects participation.

Given the multiplicity of factors that may reasonably shape different levels of participation, it is important to test the relative contribution of different theoretically relevant variables simultaneously. Doing so can minimize problems related to multiple causation and omitted variable bias. In the empirical context of the study, several of the independent variables may be correlated. Omitting theoretically important variables can therefore bias the statistical coefficients of included variables (King, Keohane, \& Verba, 1994). Specifically, the model we use to analyze our data includes variables pertaining to the household economy, the social status of the households, benefits to households from CPRs, and the accessibility of state officials (Knoke, 1988; Verba et al., 1993). We rely on some of the more commonly discussed variables in the literature on governance of common pool forest resource in South Asia to operationalize the following empirical model.

$$
\begin{aligned}
\text { Participation }= & \alpha+\beta \cdot \text { Economic }+\delta \cdot \text { Social } \\
& +\gamma \cdot \text { CPRbenefits }+\eta \cdot \text { Access } \\
& +\lambda \text { Size }+\varepsilon, \quad \varepsilon \sim N\left(0, \sigma^{2}\right),
\end{aligned}
$$

where:

Participation $=$ Degree of participation in

Economic = (Income, Land, Livestock $)$;

Social $=($ Education, Caste $)$;

CPRbenefits $=($ Firewood, Fodder $)$;

Access $=$ (Member visits, Officer visits);

Size $=$ Household size .

Our use of an ordered probit model is justified by the nature of our dependent variable: it is neither continuous, nor normally distributed. The use of an OLS model would likely lead to biased estimates for the variables.

\section{(a) The dependent variable}

Our dependent variable measures household-level participation in the user groups sponsored by the PPP. It is an ordered vari- able coded from 0 to 3 . We have coded the variable thus to reflect the degree of participation better. The criteria used in coding are as follows:

- A household is coded 0 if no household member participates in a state-sponsored CPR-management group; (1) if one person of the household is a member of a statesponsored CPR-management group; (2) if: (a) one person from the household holds an official position in a state-sponsored CPR-management group or (b) there are two household members in the CPR-management group, either as officials or as ordinary members; and (3) if three or more household members are in the CPR-management group, either as officials or as ordinary members.

The logic underlying the coding is straightforward. Simple membership in a user group translates at best into attendance at meetings, and following the decisions of the user group. However, official positions such as those of a chairman, secretary, treasurer, or accountkeeper in a user group requires greater participation from the household. Finally, if a household has several individuals who are participating in the user group, then such a higher level of participation should be reflected in the data. Our attempt to represent different levels of participation is an important part of our analysis, and a justification for the ordered probit statistical model we use.

\section{(b) Independent variables}

Our independent variables are classified into four categories corresponding to the various sources of motivation to participate in the CPR-management groups created by the PPP. The size variable on the right-hand side of the equation is a demographic variable referring to household size.

Economic condition: We use three different variables to measure the economic condition of a household, namely income, land ownership, and livestock ownership. These variables correspond to the three main types of incomes for households in the rural areas where the PPP is active. We constructed these variables in the following manner.

-Income: This indicates whether the household gets any supplementary income in addition to income from agriculture (e.g., remittances from outmigrants or government pensions). Given serious problems in 
finding out exact incomes, we focused on identifying reliably whether sampled households had any supplementary income at all. -Land: This is the household's land ownership in kathas $(1$ katha $=0.034$ ha).

-Livestock: This variable tells us the number of livestock units (LU) that a household owns. We converted the cattle, sheep, and goats owned by the household into livestock units using the following identities:

(a) 1.2 cows $=1 \mathrm{LU}$, (b) 1 buffalo $=1 \mathrm{LU}$,

(c) 5 sheep $=1 \mathrm{LU}$, (d) 4 goats $=1 \mathrm{LU}$, and

(e) two calves $=1 \mathrm{LU}$.

Social condition: In our analysis, two main variables describe the social condition of a household: education and caste. We consider education for the household by taking into account the years of education for all adult members in a household (where adult is defined as 15 years or older). Since the total number of years of education is likely to be related to the number of household members, we also include household size as a variable in the analysis. ${ }^{13}$ The caste variable is simply a dummy variable that identifies whether a household belongs to a lower caste. There is a plethora of caste categories in the Terai villages. ${ }^{14} \mathrm{~A}$ comprehensive list of these categories is extremely difficult to rank hierarchically. By defining caste as a dummy variable, we considerably simplify the analysis.

CPRbenefits: Two of our variables pertain to the level of benefits that surveyed households draw from the common pool resource. These are (a) the amount of firewood and (b) the amount of fodder that a household harvests from forests in the protected areas. Fodder and firewood constitute the most important benefits for households from the Terai forests. In our research, we also collected data on additional products such as thatch grass, reeds for handicraft production, and green manure. These benefits were available only to a small proportion of the sampled households, or are entirely unavailable to households in some of the buffer zones. As a result, we focus on firewood and fodder. These commodities were measured in bundles and headloads used annually, based on observations and estimates provided by families. Using conversion values for bundles and headloads obtained during field research, we later transformed the number of bundles and headloads into kilograms.

Access: We use two variables to indicate the accessibility of government and PPP officials to community members: Member Visit and
Officer Visit. The first measures the frequency of members' visits to the offices of the PPP per year; the second measures the frequency of government and PPP officers' visits to households (per year) to encourage them to meet the objectives of the program. A more refined way to measure access would also include the nature of these interactions. By only counting the number of interactions, our data ignore the nature of interactions. Our assumption is that since the period of data collection falls in the initial years of the implementation of the PPP, it is likely that visits by members and officials are related primarily to group formation/benefit allocation, and problems in the process of group formation/benefit allocation.

The basic information on the selected variables is presented in Table 2 .

The model and the variables we describe above help us test the four participation-related hypotheses we listed earlier in the introduction. The hypotheses are each connected to the concern that decentralization programs attempting to secure participation may not succeed in their objective owing to poor design or insufficient attention to household-level differences.

\section{RESULTS AND DISCUSSION}

Table 3 reports the estimates for the model. The model is highly statistically significant $(p<0.01)$, with a Chi-squared statistic of 62 .

Two of the three economic variablesincome and land-are statistically significant. Households with supplementary income in addition to their income from agriculture are more likely to participate in user groups created by the PPP (coefficient $=0.477$, significant at the $10 \%$ level). Similarly, households that own more land are more likely to participate to a greater extent in the groups created by the program (coefficient $=0.004$, significant at the 5\% level). The livestock variable is not statistically significant. The explanation for the statistical nonsignificance of the livestock variable might lie in its positive and statistically significant correlation with three of our other independent variables: land, household size, and income (correlation $=0.13,0.26$ and 0.25 , respectively; all significant at the $10 \%$ level).

Both the social variables are statistically significant. The high statistical significance of the caste variable confirms the hypothesis that lower-caste members participate relatively less in the user groups created by the PPP 
Table 2. Descriptive statistics for the variables used in the analysis

\begin{tabular}{lccccc}
\hline Name of variable & Number of observations & Mean & Standard deviation & Minimum & Maximum \\
\hline Participation & 230 & 0.85 & 0.80 & 0 & 3 \\
Size (number of persons) & 230 & 7.82 & 3.50 & 1 & 20 \\
Income & 230 & 0.07 & 0.25 & 0 & 1 \\
Land (kathas) & 230 & 22.88 & 40.13 & 0 & 480 \\
Livestock (units) & 230 & 3.65 & 2.51 & 0 & 16.1 \\
Education (years) & 230 & 15.79 & 16.76 & 0 & 106 \\
Caste & 230 & 0.40 & 0.49 & 0 & 1 \\
Fuelwood (tons/year) & 230 & 1.45 & 1.59 & 0 & 11.35 \\
Fodder (tons/year) & 230 & 2.30 & 3.82 & 0 & 39.14 \\
Officer visit (per year) & 230 & 2.87 & 0.65 & 0 & 4 \\
Member visit (per year) & 230 & 3.43 & 0.78 & 0 & 4 \\
\hline
\end{tabular}

Source: Field Survey, 1998-99.

Table 3. The role of economic, social, benefit, and access related variables in participation

\begin{tabular}{lcc}
\hline Name of variable & Coefficient & Standard error \\
\hline Economic variables & & \\
$\quad$ Income & $0.477^{*}$ & 0.298 \\
$\quad$ Land & $0.004^{* *}$ & 0.002 \\
$\quad$ Livestock & -0.062 & 0.035 \\
Social variables & & \\
$\quad$ Education & $-0.012^{* *}$ & 0.006 \\
$\quad$ Caste & $0.554^{* * *}$ & 0.167 \\
CPRbenefit variables & & \\
$\quad$ Firewood & $0.100^{* *}$ & 0.050 \\
$\quad$ Fodder & -0.038 & 0.025 \\
Access variables & & \\
$\quad$ Officer visit & 0.058 & 0.133 \\
Member visit & $0.396^{* * *}$ & 0.116 \\
Size & $0.139^{* * *}$ & 0.029 \\
Ancillary parameters & & \\
Cut 1 & -0.498 & 0.457 \\
Cut 2 & $0.902^{* *}$ & 0.459 \\
Cut 3 & $2.067^{* * *}$ & 0.492 \\
\hline
\end{tabular}

LR Chi-squared $(10)=61.7$; Prob $($ Chi-squared $)=0.000$.

Pseudo- $R$-squared $=0.1190$.

Note: The table presents the results of an ordered probit equation where the dependent variable is ordered from 0 to 3 . The figures in the brackets are standard errors. For the coefficients above, $* * *$ and $* * *$ indicate statistical significance at the $10 \%, 5 \%$, and $1 \%$ levels, respectively. The ancillary parameters are the cutoff points on the standardized normal distribution used to calculate predicted probabilities for each category of the dependent variable.

(coefficient $=0.554$, significant at the $1 \%$ level). The education variable has a negative sign and is statistically significant (coefficient $=-0.012$, significant at the 5\% level). This indicates that the higher the average number of years of education of the adult members in a household, the lower the likelihood of the household participating in the program.

The high statistical significance and the negative sign of the education variable is an interesting result, and needs further discussion and analysis. Some of the implications of this result are that higher education for the household may open up opportunities for educated individuals outside the village, making them both less available to participate in the PPP-sponsored user groups, and potentially less interested in participating as well. Higher levels of household education may even reduce the dependence of households on resources. This result has important policy implications as well. Better access to education and greater use of 
educational opportunities by households can enhance the goal of resource conservation at the same time as households have the possibility to improve their socioeconomic status. This inference is especially likely if education indeed helps individuals become more interested in seeking jobs outside the village. To examine this issue in more detail, we looked at the correlation between different economic variables and education. We find that education has a weak and statistically nonsignificant but positive relationship with land ownership and nonagricultural income, but not caste. Although this paper does not aim to investigate intrahousehold and gender issues related to participation, we also examined the relationships of the different economic variables with the education of men and women in the household. When we disaggregated education levels by gender, the correlation of men's and women's education with land ownership and income remained statistically nonsignificant at the 10\% level with one exception: there is a weak but positive and statistically significant relationship between caste and women's education - upper caste women are better educated (correlation $=0.149$, significant at the $10 \%$ level).

We probed deeper into our data in light of the interesting result related to education. We know from our data that men are more educated than women (mean years of education for adult men are twice those for adult women), they are more likely to be in positions of authority in the PPP-sponsored user groups, and they are more likely to be employed in off-farm employment positions. If these conditions hold, it may be the case that our model underestimates the correlation between education and participation. If the assumptions stated above are on the mark, we should expect the variable for men's education to have a stronger positive relationship with participation than the variable for total household education or for women's education. To test the hypothesis, we reanalyzed the data after coding men's and women's education separately, and substituting the household-level education variable with (a) the two new variables for men's and women's education; (b) men's education; and (c) women's education. The fit of all the three tested models remained close to the results reported in Table 3 (Chi-square value varied between 55 and 57, and the models were statistically significant at $p<0.001)$. But the disaggregated education variables were not statistically significant in any of the three models.
In the reported model, the coefficient of the household education variable is -0.012 (statistically significant at the $5 \%$ level). In the three new models we tested, the coefficients of men's and women's education were statistically not significant, and varied between 0.001 and -0.012 . The coefficients of nearly all the other variables remained similar to those reported in this paper. The data thus suggest that the household education as a whole is correlated better with levels of household participation than when disaggregated by gender, and that our results are not sensitive to a variety of different ways of operationalizing the education variable to take gender into account. However, further research where participation is also disaggregated by gender might reveal new patterns that our data do not indicate since we did not collect information on women's and men's participation separately.

Of the two variables related to benefits from the resource (firewood and fodder), firewood is statistically significant. This means that as anticipated, households that use higher amounts of firewood from the forest are also more likely to try to participate in the program and to influence decision making in local groups through participation (coefficient $=0.1$, statistically significant at the 5\% level). Although we did not collect data on benefits to households as a proportion of their overall requirements of fodder and firewood, we estimated the per capita benefits from forests as a potentially better measure of benefits to households from the forest. The coefficient for both firewood and fodder became smaller as expected, but the levels of statistical significance did not change appreciably (the coefficient for firewood benefits per capita is 0.07 , and it is statistically significant at the $5 \%$ level; the coefficient for fodder is statistically nonsignificant). One reason fodder is not statistically significant may be that households may more commonly graze their animals in the open rather than stall feed them. ${ }^{15}$

One of the access variables is also statistically significant. Greater accessibility of the Parks and People's office to households increases participation in the program. The more visits members of the user groups make to PPP offices, the more likely it is that they are participating at a higher level in the user groups (coefficient $=0.396$, statistically significant at the $1 \%$ level). In contrast, visits by government officials do not have a statistically significant correlation with variations in levels of participation in user groups. 
Finally, the size of the household is also highly statistically significant. A larger size of the household bears a strong positive and statistically significant relationship with levels of participation in PPP-sponsored user groups (coefficient $=0.139$, statistically significant at the $1 \%$ level).

Table 4 presents the predicted probabilities that a household will participate to a substantial degree in the PPP-sponsored user groups (category 2 of the dependent variable), for the minimum and maximum values for each statistically significant variable in Table 4, holding all other variables at their mean value. ${ }^{16}$ The last column presents the difference in the probability of participation as the variable changes from its minimum to maximum.

Among the economic variables, the probability of participation increases from 0.094 to 0.191 if households have some supplementary income. The effect on participation of variation in land ownership from the lowest to the highest observed value is also large: probability of participation increases from 0.080 to 0.341 . Being from an upper caste increases the probability of participation of a household by 0.111 . More education has a negative effect on the probability of participation. At the maximum value of education for a household, the probability of its participation in PPP-sponsored user groups declines by 0.217 . More benefits to households from forests increase the likelihood of participation. With other variables held constant at their means and the dichotomous variables at 0 , if firewood harvests increase from the minimum to the maximum value, the probability of participation increases by 0.226 .
Some of the greatest increases in the probability of participation stem from better access of the PPP office to households, and differences in household size. As the frequency of visits by households to the PPP offices rises from a minimum to a maximum, the probability of participation increases by 0.310 . Some reasons that may account for such a finding is that greater access to government offices and officials helps disseminate greater information about available program benefits to villagers who are interested in such information. Visiting government officials can also provide the same information. But unless households are interested in such information, it does not make much of a difference to the likelihood of participation. Further, it is likely that the well-off and the higher-caste households enjoy greater access to government officials and therefore undertake more visits. However, in light of the fact that our data are from a single time period, we cannot discount the possibility that there is reverse causality at work here-greater participation in the PPPsponsored user groups is what leads to more visits by households to PPP offices. There is one likely reason that may mitigate against such an interpretation - if it is participation that promotes interactions between households and government officials, then households participating more in the PPP should also receive more visits from government officials. But the coefficient for officials' visits to participating households is both small and statistically nonsignificant. We can cautiously infer that the data provide some support for an argument to improve the ability of marginal and poorer households to access government offices and

Table 4. Change in probability of participation as statistically significant variables vary from a minimum to a maximum

\begin{tabular}{lccc}
\hline Name of variable & At minimum value & At maximum value & Difference between minimum and maximum \\
\hline Economic variables & & & 0.097 \\
$\quad$ Income & 0.094 & 0.191 & 0.261 \\
$\quad$ Land & 0.080 & 0.341 & 0.111 \\
Social variables & 0.094 & 0.205 & -0.226 \\
$\quad$ Caste & 0.281 & 0.055 & 0.226 \\
$\quad$ Education & 0.074 & & \\
Dependence variables & & 0.300 & 0.310 \\
$\quad$ Firewood & 0.064 & 0.374 & 0.402 \\
Access variables & 0.015 & 0.417 & \\
$\quad$ Member visit & & & \\
Size &
\end{tabular}

Note: This table reports predicted probabilities of being in category 2 of the Participation variable. Probabilities are reported at the minimum and maximum values of the statistically significant variables in Table 3 , holding other variables at their mean values, and dummy variables at 0 . The final column reports the change in probability as the independent variable changes from a minimum to a maximum. 
officials if greater participation from such households is desired as a part of decentralization policy reforms.

Finally, as the size of the household increases from a minimum to a maximum, the probability of participation also rises from 0.015 to 0.417 .

The information in Table 4 is interesting both because of its policy implications, and for its value as an indication of the social and economic relationships pertaining to participation. Obviously, it is not possible to use policy to help households make transitions across minimum to maximum values for several variables in Table 4. Individuals are born into a caste, and changes are possible only over multiple generations, if at all. Even the level of land ownership is not really under the control of those framing environmental policies. But some of the other variables may reasonably be modified through policy measures. Two such variables are education and visits by members. Higher education levels are especially attractive as a policy option because of the important positive impacts of education on other aspects of rural livelihoods as well. Further, governmentsponsored user groups can improve the frequency of visits by poorer and socially less powerful user group members by taking advantage of the likelihood that their opportunity cost of time is lower than that of richer and socially more powerful households. Locating the program office closer to settlements, requiring regular attendance at more frequent meetings held at the program office, and tying benefits from the program to regular attendance may make richer villagers less inclined to participate since they are likely to lose more by committing greater amounts of time to program activities. Similarly, promoting income-generation activities that do not depend on land ownership but on education and training in nonagricultural occupations are also likely to benefit those with a lesser amount of land.

\section{CONCLUSION}

We began this paper by asking the question, "Who participates in government-sponsored CPR-management programs?" The results of our analysis of an environmental policy decentralization program are in broad agreement with what scholars of development have argued for long. As Schwartz pointed out for community development, "externally introduced re- sources-technical, economic, political, social service - are distributed along lines of existing inequality and thus reinforce it unless accompanied by radical, massive institutional changes..." (1978: p. 249). Our results are certainly not as dramatic as the above assertion by Schwartz. Indeed, the PPP attempts to create socioeconomic change mainly to improve the livelihood of participants, and reduce pressure on park resources. But we find that richer and upper caste households have a higher probability of joining the user groups that the PPP has created to decentralize environmental decision making and distribute benefits from environmental resources. More specifically, large landownership, having a high income, and being in an upper caste facilitate greater participation in PPP-sponsored user groups. These results are relevant in the context of work by other scholars that also shows how better-off and more powerful local groups tend to appropriate greater levels of benefits from decentralized community-level groups (Adhikari et al., 2004; Crook, 2003; Ostrom, 2005; Weinberger \& Jutting, 2001).

The results of our research are especially important in the context of significant political asymmetries in rural Nepal. Although decentralization of environmental policy cannot address or redress the political inequalities that are at least partially responsible for the violence that has become an endemic feature of the rural Nepalese context, it can at least attempt not to exacerbate such inequalities. Indeed, this observation is relevant to the issue of elite domination elsewhere as well. Whether it is bias in existing forms of program implementation that encourages the economically and socially better-off to participate more, or whether they are better able to participate because of microlevel social and political connections with government officials and greater access to existing resources is an open question. Indeed, overt bias toward the better-off rural residents is difficult to show in the design and implementation structure of the PPP. However, the more relevant point is that even without bias in favor of the richer, more powerful rural residents, it is those with more land, more sources of income, and a highercaste status who tend to participate more.

Our results constitute a note of caution for the way many decentralization programs are implemented in relation to environmental policy: in a relatively neutral fashion as far as securing the participation of the poor and socially marginal groups is concerned. If there is 
a greater propensity on the part of the upper caste, the landed, and those who have more sources of income to participate more in state-sponsored local organizations, then decentralization programs that are neutral in their design as far as eliciting participation is concerned will likely not affect equity at the local level. Indeed, they may well exacerbate inequality. Those concerned with equity and democracy in common pool resource governance, therefore, need to consider more carefully the design and implementation of community-oriented decentralization programs so that participation can be biased in favor of the poor and the marginal.

Our statistical analysis points to two important policy-relevant findings that are not new, but directly concern the design of programs to secure greater participation of the poorer and more marginal groups. The model suggests that households initiating more interactions with government officials by visiting the offices of the PPP are also more likely to be participants in the user groups of PPP. There may be a natural overlap between those who are better-off, and those with higher access to government offices. But since the participation-related effectiveness of decentralization programs can be enhanced by improving the ability of households to contact and access government officials, the promotion of decentralization programs can be accompanied by specific steps to encourage the economically and socially more marginal local residents to visit government offices. Such encouragement may be achieved in two ways: by locating program offices closer to poorer settlements, and by requiring regular attendance at frequent meetings and tying benefits from the program to regular attendance.

Improving access of the poor and landless to local government offices and officials through better information provision and greater dialog can also have an important positive impact on broadening participation. Indeed, such donor support has important bearing on the participation of the poor according to studies in other contexts as well (Weinberger \& Jutting, 2001, p. 1402). It is important also to note that at least for some poor households, the costs of regular participation may be quite high. And for the really poor, programs such as the PPP may be ill suited to address poverty or secure participation in resource conservation. Programs explicitly aimed at addressing chronic poverty may be the only mechanisms to support such groups, although even such programs have not always worked well.

The results related to household-level education also have direct implications for participation as well as consumption of benefits from park resources. Our data highlight the importance of total household education on participation: Higher education has a negative relationship with participation in the user groups of the PPP. The relationship is likely a result of declining interest in the PPP, and its benefits as higher levels of education make it possible to look for other sources of employment and income, and possibly migrate out of the settlement. The exact balance of the impact on participation as a result of greater education, and remittances from outmigrants to their homes needs further investigation.

To conclude, one way to enhance the participation of poor, lower-caste groups in local user groups is to take advantage of their lower opportunity cost of time, and tie program benefits to greater commitment of time (frequent local meetings, and regular attendance at these meetings). Another way to do so, our data and analysis indicate, is by creating greater access to education among members of user groups. Other scholars have pointed to mechanisms for promoting equality that allow the poor to trade their shares of benefits from the commons, require membership of lower-caste groups in the decision-making committees of local user groups, or argue for greater accountability of decision makers (Adhikari et al., 2004; Crook, 2003; Nightingale, 2002). Only when community-oriented decentralization programs succeed in securing greater participation from more vulnerable groups will it be possible to meet the objectives of distributing benefits more equitably and promoting local democracy.

\section{NOTES}

1. Decentralization has seemingly become popular only since the mid-1980s. But earlier claims by governments that they are decentralizing decision-making authorities can be discerned in many areas of the developing world.
See Agrawal and Ribot (1999) for a more general statement about waves of decentralization in Africa and South Asia. 
2. See Ostrom (1990) and Ostrom, Gardner, and Walker (1994) for a discussion of common pool resources and an analysis of the conceptual differences between common pool resources and common property regimes.

3. We interviewed 240 households in our fieldwork. But we discarded 10 responses because of incomplete answers, or because of data reliability concerns. The final statistical analysis was carried out on the remaining 230 household responses.

4. The legal definition of buffer zones is areas "set aside around a national park or reserve... for granting opportunities to local people to use forest products on a regular basis" (UNDP, 1994, p. 3). An area of controlled land use, a buffer zone, as the name suggests, "separates a protected area from direct human or other pressures and provides valued benefits to neighboring rural communities" (Nepal \& Weber, 1994, p. 333).

5. For studies of biodiversity in the protected areas in Nepal and their economic significance see Brown (1997) and Wells (1993). For their utility to subsistence users in terms of products such as grass, fodder, and fuelwood, see Byers (1996) and Heinen and Yonzon (1994).

6. Even a partial list of agencies that have supported environmental conservation activities in Nepal would include Action Aid, ADB (Asian Development Bank), AusAID (Australian Government's Overseas Aid Program), CARE International, DANIDA (Danish Agency for Development Assistance), EuropeAid, FAO (Food and Agriculture Organization), GEF (Global Environment Facility), GTZ (German Society for Technical Cooperation), SNV (Netherlands Development Organization), UNDP (United Nations Development Program), WWF (World Wildlife Fund), USAID (United States Agency for International Development), and the World Bank.

7. Similar conflicts are also present around protected areas in other parts of the world (Hill, 2002; Vandergeest, 1996).

8. The buffer zone area for the two parks (Chitwan and Bardia) has been identified and gazetted. For the three wildlife reserves (Suklaphanta, Parsa, and Kosi Tappu), the area has been identified, but survey work for demarcation and official notification was still under way at the time of this study.

9. The objective of the PPP is the coverage of all protected areas in Nepal. In 1998, the project was launched in two additional areas outside the Terai region: the Rara and the Khaptad National Parks. In the second phase, there is also a shift in emphasis toward community-based approaches and on development and self-reliant socioeconomic development.

10. The International Forest Resources and Institutions (IFRI) Program was initiated in 1992 at Indiana University. The program comprises a network of Collaborating Research Centers in a number of countries including Nepal, and aims to elucidate links between institutional arrangements and forest management. The chief means of data collection is a set of 10 research protocols focusing on biophysical, socioeconomic, and institutional variables in a given site (Gibson, McKean, \& Ostrom, 2000; Poteete \& Ostrom, 2004). Collectively, these protocols include nearly 1,000 variables.

11. Availability of off-farm income to households is also an indirect measure of the articulation of a given family with market opportunities - another relevant variable affecting propensity to participate in local resource governance institutions (Beckley, 1998).

12. Transformation of different types of animals into a standardized livestock unit, based on the average weight of different animals is common in the literature on grazing systems (FAO, 2003, p. 2). Conversion into standardized units is complicated, however, by variations in average animal weights across different contexts. Tropical livestock units are typically taken to be $250 \mathrm{~kg}$ of animal weight (Sidahmed, 1993). The more important element here is to take into account conversion ratios across species (Thorton et al., 2002). We have relied on the above publications to arrive at the conversion factors used in the analysis. To examine the robustness of our results, we also conducted our analysis keeping browsers (sheep and goats) and grazers (cows and buffaloes) distinct, but this refinement produced little difference in the statistical significance of livestock, or in the value of the coefficients of other variables.

13. As discussed earlier, household size is also an important variable for other reasons, including the possibility that it reflects labor availability within the household, and the household's ability to withstand smooth income fluctuations over time.

14. The major groups coded as upper caste are Brahman, Chhetri, and Thakuri. Lower castes included Biswakarma, Damai, Giri, Kami, Koiri, Lohar, Sanyasi/ Yogi, and Sunar. Dhami, Majhi, and Tharu are the tribal groups we encountered who strictly speaking do not have a caste status. Given their low social status, however, we coded them as low caste as well. 
15. The figures in Table 2 support this inference. Sampled households own, on the average 3.5 livestock units. Even if one takes a conservative estimate of $5 \mathrm{~kg}$ of dry feed per animal, this would imply a total annual fodder requirement of approximately 6.4 tons per year. The mean fodder harvest level by sampled households, however, is 2.3 tons-just over $35 \%$ of what is needed.
16. We consider probabilities for the level of participation where a household has more than one member participating in the program's user groups, or a member as the official in the Program-sponsored user groups. This is category 2 of the dependent variable. We did not examine category 3 since there are very few households who have individuals in official positions as well as multiple members in the program (only 7 our of 230 observations).

\section{REFERENCES}

Adhikari, B., Di Falco, S., \& Lovett, J. C. (2004). Household characteristics and forest dependency: Evidence from common property forest management in Nepal. Ecological Economics, 48(2), 245257.

Agarwal, B. (2001). Participatory exclusions, community forestry, and gender: An analysis for South Asia and a conceptual framework. World Development, 29(10), 1623-1648.

Agrawal, A., \& Ostrom, E. (2001). Collective action, property rights and decentralization in resource use in India and Nepal. Politics and Society, 29(4), 485-514.

Agrawal, A., \& Ribot, J. C. (1999). Accountability in decentralization: A framework with South Asian and West African cases. Journal of Developing Areas, 33, 473-502.

Almond, Garbriel A., \& Verba, S. (1963). The civic culture: Political attitudes and democracy in five nations. Princeton: Princeton University Press.

Andersson, K. P., Gibson, C. C., \& Lehoucq, F. (2004). The politics of decentralized natural resource governance. PS-Political Science and Politics, 37(3), 421-426.

Beckley, T. M. (1998). The nestedness of forest dependence: A conceptual framework and empirical exploration. Society and Natural Resources, 11(2), 101-120.

Botchway, K. (2001). Paradox of empowerment: Reflections on a case study from Northern Ghana. World Development, 29(1), 135-153.

Brown, K. (1997). Plain tales from the grasslands: Extraction, value and utilization of biomass in Royal Bardia National Park, Nepal. Biodiversity and Conservation, 6, 59-74.

Budhathoki, P. (2003). Buffer zone initiatives in Nepal: Balancing the scales. Mimeo. http://www.protectedlandscapes.org/paper1.html. Accessed on September 12, 2004.

Byers, A. C. (1996). Historical and contemporary human disturbance in the Upper Barun Valley, Makalu-Barun National Park and Conservation Area, East Nepal. Mountain Research and Development, 16, 235-247.

Crook, R. C. (2003). Decentralisation and poverty reduction in Africa: The politics of local-central relations. Public Administration and Development, 23(1), 77-88.

Dahl, R. A. (1961). Who governs? New Haven: Yale University Press.
De Vries, M. S. (2000). The rise and fall of decentralization: A comparative analysis of arguments and practices in European countries. European Journal of Political Research, 38(2), 193-224.

DNPWC (Department of National Parks and Wildlife Conservation) (1998). Guidelines for the preparation of buffer zone user group plan. Park and People Program (Nep/94/001). Park and People Program, DNPWC, Kathmandu.

Fiszbein, A. (1997). The emergence of local capacity: Lessons from Colombia. World Development, 25(7), 1029-1043.

FAO (Food and Agriculture Organization) (2003). Livestock sector brief: LAO PDR. Rome: FAO.

Gibson, Clark C., McKean, Margaret, \& Ostrom, E. (Eds.) (2000). People and forests: Communities, institutions, and governance. Cambridge: MIT Press.

Heinen, J. T., \& Kattel, B. (1992). A review of conservation legislation in Nepal: Past progress and future needs. Environmental Management, 16(6), 723-733.

Heinen, J. T., \& Yonzon, P. B. (1994). A review of conservation issues and programs in Nepal: From a single species focus toward biodiversity protection. Mountain Research and Development, 14, 61-76.

Hill, C. M. (2002). Primate conservation and local communities: Ethical issues and debates. American Anthropologist, 104(4), 1184-1194.

Hirschman, A. O. (1970). Exit, voice, and loyalty: Responses to declines in firms, organizations, and states. Cambridge: Harvard University Press.

Kant, S. (2000). A dynamic approach to forest regimes in developing economies. Ecological Economics, 32(2), 287-300.

Kaushal, K. K., \& Kala, J. C. (2004). Applying the sustainable livelihood approach to joint forest management projects in India. International Forestry Review, 6(1), 13-18.

Keiter, R. B. (1995). Preserving Nepal's national parks: Law and conservation in the developing world. Ecological Law Quarterly, 22, 591-675.

King, G., Keohane, R., \& Verba, S. (1994). Designing social inquiry: Scientific inference in qualitative research. Princeton: Princeton University Press.

Knoke, D. (1988). Incentives in collective action organizations. American Sociological Review, 53(3), 311-329.

Kumar, S. (2002). Does "participation" in common pool resource management help the poor? A social costbenefit analysis of joint forest management in 
Jharkhand, India. World Development, 30(5), 763-782.

Lise, W. (2000). Factors influencing people's participation in forest management in India. Ecological Economics, 34(3), 379-392.

Moe, T. M. (1980). A calculus of group membership". American Journal of Political Science, 24(4), 593632.

Naik, G. (1997). Joint forest management: Factors influencing household participation. Economic and Political Weekly, 32(48), 3084-3089.

Nepal, S. K., \& Weber, K. (1994). A buffer zone for biodiversity conservation: Viability of the concept in Nepal's Royal Chitwan National Park. Environmental Conservation, 21, 333-341.

Netting, R. McC. (1981). Balancing on an Alp. Cambridge: Cambridge University Press.

Nightingale, A. J. (2002). Participating or just sitting in? The dynamics of gender and caste in community forestry. Journal of Forestry and Livelihoods, 2(1), $17-24$.

Olson, M. (1965). The logic of collective action. Cambridge: Harvard University Press.

Ostrom, E. (1990). Governing the commons. New York: Cambridge University Press.

Ostrom, E. (2005). Understanding institutional diversity. New York: Cambridge University Press.

Ostrom, E., Gardner, R., \& Walker, J. (1994). Rule, games, and common pool resources. Ann Arbor: University of Michigan Press.

Poteete, A. R., \& Ostrom, E. (2004). Heterogeneity, group size and collective action: The role of institutions in forest management. Development and Change, 35(3), 435-461.

Ribot, J. C. (2002). Democratic decentralization of natural resources: Institutionalizing popular participation. Washington, DC: World Resources Institute.

Sidahmed, A. E. (1993). Institutional and economic framework conditions for livestock development in developing countries and their interrelationships. Plenary paper, Proceedings of the international conference on livestock development in developing countries, Weilheim, Germany, May 17-20, 1993.
Stem, C. J., Lassoie, J. P., Lee, D. R., Deshler, D. D., \& Schelhas, J. W. (2003). Community participation in ecotourism benefits: The link to conservation practices and perspectives. Society and Natural Resources, 16(5), 387-413.

Teklu, T., \& Asefa, S. (1999). Who participates in labor intensive public works in Sub-Saharan Africa: Evidence from rural Botswana and Kenya. World Development, 27(2), 431-438.

Thorton, P. K, Kruska, R. L., Henninger, N., Krisjanson, P. M., Reid, R. S., Atieno, F., Odero, A. N., \& Ndegwa, T. (2002). Mapping poverty and livestock in the developing world. Nairobi: ILRI (International Livestock Research Institute).

UNDP (United Nations Development Program) (1994). Parks and People Project Document (DNPWC/ UNDP). His Majesty's Government of Nepal, Kathmandu.

UNDP (2000). Consolidating Conservation through People's Participation: Parks and People Programme (DNPWC/UNDP). His Majesty's Government of Nepal, Kathmandu.

Vandergeest, P. (1996). Property rights in protected areas: Obstacles to community involvement as a solution in Thailand. Environmental Conservation, 23(3), 259-268.

Verba, S., Schlozman, K. L., Brady, H., \& Nie, N. H. (1993). Citizen activity: Who participates? What do they say? American Political Science Review, 87(2), 303-318.

Weinberger, K., \& Jutting, J. P. (2001). Women's participation in local organizations: Conditions and constraints. World Development, 29(8), 1391-1404.

Wells, M. (1993). Neglect of biological riches: The economics of nature tourism in Nepal. Biodiversity and Conservation, 2, 445-464.

Willis, E., Christopher da, C. B. G., \& Haggard, S. (1999). Decentralization in government: Latin America. Latin American Research Review, 34(1), 7-56.

Wunsch, J. S., \& Olowu, D. (1997). Regime transformation from below: Decentralization, local governance, and democratic reform in Nigeria. Studies in Comparative International Development, 31(4), 66-82.

Available online at www.sciencedirect.com

science $d$ DiRect $^{\circledR}$ 